Arq. Bras. Med. Vet. Zootec., v.68, n.4, p.1007-1014, 2016

\title{
Synthetic pigments for Japanese quail fed diets with sorghum
}

[Pigmentantes sintéticos para codornas japonesas alimentadas com rações à base de sorgo]

\author{
A.M.A. Moura', T.V.Melo ${ }^{2}$, D.J.A. Miranda ${ }^{3}$ \\ ${ }^{1}$ Instituto de Ciência e Tecnologia em Biomodelos - Fundação Oswaldo Cruz - Manguinhos, RJ \\ ${ }^{2}$ Instituto de Ciências Agrárias - Universidade Federal do Vale de \\ Jequitinhonha e Mucuri - Campus Unaí - Cachoeira, MG \\ ${ }^{3}$ Universidade Federal do Rio Grande do Sul - Porto Alegre, RS
}

\begin{abstract}
Corn is the major energy ingredient in diets, and many ingredients have been tested aiming to replace it. In this regard, sorghum stands out for its chemical profile similar to that of corn. However, because it is low in carotenoids, its inclusion in diets reduces the egg yolk color pigmentation, which can be corrected by the addition of synthetic pigments. This study aimed to evaluate the performance and egg quality of Japanese quail (Coturnix japonica) supplemented with red (canthaxanthin) and yellow (apo-ester 10\%) synthetic pigments. A total of 150 quail at 70 days of age were distributed according to the experimental diet [R1: corn-based control diet (DC); R2: sorghum-based diet (DS); R3: DS + yellow; R4: DS + yellow + red; and R5: DS + red] with six replications and five birds per experimental unit, for 28 days. Performance, egg quality, yolk color, and feed cost characteristics were evaluated. Regression equations were estimated for the effects of color as a function of periods, and treatment means were compared by Tukey's test at 0.05 probability. There was no significant effect $(\mathrm{P}>0.05)$ of additives on the quail productive traits. However, addition of synthetic pigments significantly improved the chromatic profile of the yolks $(\mathrm{P}<0.05)$. Inclusion of synthetic pigments improves yolk color, but should be evaluated according to market demands.
\end{abstract}

Keywords: chromatic analysis, canthaxanthin, yolk color

\section{RESUMO}

O milho é o principal ingrediente energético nas rações. A fim de substitui-lo, vários ingredientes foram testados. Nesse sentido, destaca-se o sorgo, pois apresenta perfil bromatológico semelhante ao do milho. No entanto, por ser deficiente em carotenoides, sua inclusão na ração reduz a pigmentação da gema do ovo, o que pode ser corrigido por meio da adição de pigmentos sintéticos. Objetivou-se, com este estudo, avaliar o desempenho zootécnico e a qualidade dos ovos de codornas japonesas (Coturnix japonica) suplementadas com os pigmentantes sintéticos vermelho (cantaxantina) e amarelo (apoéster 10\%). Foram utilizadas 150 codornas japonesas com 70 dias de idade, distribuídas de acordo com a ração experimental (R1: ração referência à base de milho; R2: ração à base de sorgo (RS); $R 3: R S$ + amarelo; R4: $R S$ + amarelo + vermelho; R5: $R S$ + vermelho), com seis repetições e cinco aves por unidade experimental, durante 28 dias. Foram avaliadas as características de desempenho, qualidade dos ovos, cor da gema e custo das rações. Equações de regressão dos efeitos da cor em função dos períodos foram estimadas, e as médias de tratamento foram comparadas pelo teste de Tukey com 0,05 de probabilidade. Não houve efeito significativo $(P>0,05)$ dos aditivos sobre as características produtivas das codornas. Entretanto, a adição de pigmentantes sintéticos melhorou significativamente o perfil cromático das gemas dos ovos de codornas $(P<0,05)$. A inclusão de pigmentantes sintéticos melhora a cor das gemas, porém deve ser avaliada de acordo com as exigências de mercado.

Palavras-chave: análise cromática, cantaxantina, cor da gema

Recebido em 9 de fevereiro de 2015

Aceito em 22 de dezembro de 2015

E-mail: antoniol@fiocruz.br 


\section{INTRODUCTION}

Quail farming is a growing activity of the poultry sector that has generated jobs and income to thousands of producers. In Brazil, these producers raise around 12 million quail, mostly for egg production. The quail nutrition has historically followed and referred to protocols adopted for broiler and laying hens. However, because it is a different species, feeding programs had to be established from experiments to evaluate the nutritional profiles of ingredients and determine the specific requirements for Japanese quail (Coturnix japonica).

Corn is the energy ingredient at highest proportion in formulations, and many ingredients have been tested aiming to replace it. Of the most commonly used substitutes, low-tannin grain sorghum stands out for its chemical profile that is similar to that of corn, for being economically viable, and for not compromising poultry performance. However, the sorghum is deficient in xantophils and carotenoids, and its inclusion in diets reduces the color intensity of the quail egg yolk (Moura et al., 2010a).

The yolk color intensity is a sensory trait with market importance, as it is a preference criterion for the consumer, who usually associates yolk color with vitamin content (Seibel et al., 2009). However, the yolk color can be kept or enhanced with the addition of synthetic (Garcia et al., 2002) and natural (Moura et al., 2011) pigments.

Synthetic yellow pigments occur in the nature as a metabolic product of apocarotene. Its commercial form is the ethyl ester $\beta$-apo- 8 carotene, or $10 \%$ apo-ester. The synthetic red pigment is $10 \%$ canthaxanthin $\left(4,4^{\prime}\right.$-diketo- $\beta$ carotene), and both are utilized to pigment the yolk color and the skin and feet of broilers (Garcia et al., 2002).

Given the foregoing, this study aimed to evaluate the effect of yellow (apo-ester 10\%) and red (canthaxanthin 10\%) synthetic pigments on performance and egg quality of Japanese quail fed a sorghum-based diet.

\section{MATERIALS AND METHODS}

The experiment was conducted in the Laboratory of Non-Ruminant Digestibility, at the
Department of Animal Science of Universidade Federal Rural de Pernambuco (UFRPE), for 28 days, divided into four seven-day experimental periods. The development of this study was approved by the Ethics Committee on Animal Use, under license L-0042/2012.

A total of 150 female Japanese quail (Coturnix japonica) (Temminck and Schlegel, 1849) of the Fujikura line, at 75 days of age, with $165.46 \pm 3.6$ $\mathrm{g}$ average weight and average egg productivity around $90 \%$ were used in this experiment. Mean data for the following performance variables were evaluated: bird weight $(\mathrm{g})$, egg production (\%/quail/day), feed intake (g/quail/day), egg weight (g), egg mass (g egg/quail/day), and feed conversion (g diet per mass and per dozen eggs). Egg quality was determined by the measurements average egg weight (g), yolk weight (g), albumen weight (g), shell weight (g), shell thickness $(\mu \mathrm{m})$, and yolk color, using the colorimetric score (DSM fan) and directreflectance chromatic evaluation (Minolta colorimeter) methods.

After the batches were standardized by body weight and egg production, the quail were housed in 30 metabolic cages $(33 \times 25 \times 20 \mathrm{~cm})$ in a completely randomized design with split-plots repeated over time, composed of five experimental diets, as follows: R1: corn-based positive control (DC); R2: sorghum-based negative control (DS); R3: DS + yellow (DSY); R4: DS + yellow + red (DSYR); and R5: DS + red (DSR), with six replications containing five quail. Plots consisted of the experimental diets, while subplots were the four observation periods (7th, 14th, 21st, and 28th days).

Experimental diets were formulated based on low-tannin sorghum, plus a corn-based diet as positive control, with the inclusion of yellow (ethyl-ester- $\beta$-apo- 8 -carotene, or apo-ester $10 \%$ $\mathrm{DSM}^{\circledR}$ ) and red (canthaxanthin 10\% $\mathrm{DSM}^{\circledR}$ ) synthetic pigments replacing an inert, as described in Table 1. Calculations for the formulation of the diets were made on Super Crac 5.0 software, according to the nutritional requirements of Japanese layer quail described by the National Research Council (Nutrient...,1994), except for crude protein and calcium, which were based on recommendations of Oliveira et al. (1999) and Barreto et al. (2007), respectively. The apparent metabolizable 
energy of corn, sorghum, soybean meal, and refined soybean oil were adjusted for values determined by Moura et al. (2010b). Chemical analyses were performed in the Laboratory of Animal Science and Animal Nutrition at Universidade Estadual do Norte Fluminense Darcy Ribeiro, following Silva and Queiroz (2002).

A lighting program was adopted with $17 \mathrm{~h}$ of light per day, controlled by an automatic timer.
Temperatures and relative humidity were recorded by digital thermo-hygrometers. Water and diet were supplied ad libitum, and the intake was calculated at the end of each week as the difference between the amount of feed supplied and refusals. Eggs were collected and weighed daily on a $0.01 \mathrm{~g}$ precision scale for calculations of production (\% eggs/quail/day), average weight $(\mathrm{g})$, and egg mass (g egg/quail/day).

Table 1. Centesimal and chemical composition of experimental diets

\begin{tabular}{|c|c|c|c|c|c|}
\hline \multirow{2}{*}{ Ingredient } & \multicolumn{5}{|c|}{ Diet } \\
\hline & $\mathrm{DC}$ & DS & DSY & DSYR & DSR \\
\hline Ground corn grain & 57.89 & -- & -- & -- & -- \\
\hline Low-tannin sorghum & -- & 57.89 & 57.89 & 57.89 & 57.89 \\
\hline Soybean meal & 31.15 & 27.24 & 27.24 & 27.24 & 27.24 \\
\hline Calcitic limestone & 6.50 & 6.55 & 6.55 & 6.55 & 6.55 \\
\hline Refined soybean oil & 0.02 & 3.85 & 3.85 & 3.86 & 3.85 \\
\hline Dicalcium phosphate & 1.34 & 1.34 & 1.34 & 1.34 & 1.34 \\
\hline Vitamin-mineral supplement $^{1}$ & 0.50 & 0.50 & 0.50 & 0.50 & 0.50 \\
\hline Salt $(\mathrm{NaCl})$ & 0.333 & 0.33 & 0.33 & 0.33 & 0.33 \\
\hline L-lysine $\mathrm{HCl} 99 \%$ & 0.125 & 0.29 & 0.29 & 0.29 & 0.29 \\
\hline DL-methionine $99 \%$ & 0.097 & 0.17 & 0.17 & 0.17 & 0.17 \\
\hline L-threonine $98.5 \%$ & -- & 0.08 & 0.08 & 0.08 & 0.08 \\
\hline Inert $^{2}$ & 2.02 & 1.72 & 1.72 & 1.72 & 1.70 \\
\hline Apo-ester $10 \%$ & -- & -- & 0.004 & 0.004 & 0.004 \\
\hline Canthaxanthin $10 \%$ & -- & -- & -- & 0.003 & 0.003 \\
\hline Antioxidant (BHT) & 0.01 & 0.01 & 0.01 & 0.01 & 0.01 \\
\hline Feed cost $(\mathrm{R} \$ / \mathrm{kg})$ & 0.71 & 0.70 & 0.77 & 0.85 & 0.85 \\
\hline \multicolumn{6}{|c|}{ Calculated chemical composition } \\
\hline Metabolizable energy (Kcal/kg) & 2,900 & 2,900 & 2,900 & 2,900 & 2,900 \\
\hline Crude protein, $\%$ & 19.0 & 19.0 & 19.0 & 19.0 & 19.0 \\
\hline Calcium, \% & 3.00 & 3.00 & 3.00 & 3.00 & 3.00 \\
\hline Available phosphorus, $\%$ & 0.35 & 0.35 & 0.35 & 0.35 & 0.35 \\
\hline Total lysine, $\%$ & 1.10 & 1.10 & 1.10 & 1.10 & 1.10 \\
\hline Methionine + cystine, $\%$ & 0.70 & 0.70 & 0.70 & 0.70 & 0.70 \\
\hline Sodium, \% & 0.15 & 0.15 & 0.15 & 0.15 & 0.15 \\
\hline
\end{tabular}

${ }^{1}$ Provides per kg: methionine - 218,000mg; vit. B12 - 10,000 mcg; folic acid - 400mg; calcium pantothenate 3,000mg; biotin - 10mg; choline - 126,000mg; niacin - 7,000mg; pyridoxine - 800mg; thiamine - 800mg; riboflavin 1,200mg; menadione - 500mg; vit. A - 2,000,000 IU; vit. D3 - 50,000 IU; vit. E - 10,000 IU; Cu - 2,000mg; Fe 16,000mg; I - 200mg; Mn - 18,000mg; Zn - 14,000mg; Se - 10,000 mcg. ${ }^{2}$ Washed sand.

To determine the yolk, albumen, and shell weights and shell thickness, five whole eggs from each plot were collected daily, at random, during the five last days of the experiment. Eggs were cracked and yolks were separated manually and weighed, and shells were dried in a forcedair oven for $24 \mathrm{~h}$ at $105{ }^{\circ} \mathrm{C}$ and weighed again. The albumen weight was obtained as the difference between the egg weight and the weights of shell and yolk. Shell thickness, including the membranes, was measured by reading four different points in the equatorial region using an external micrometer, as described by Nordstrom and Ousterhout (1982).

Yolk color was analyzed in the Laboratory of Food Physicochemical Analyses at the Department of Domestic Sciences of UFRPE. A DSM $^{\circledR}$ Yolk Color Fan (DSM, 2008) was used, in which the yolk color was compared with the 
color scale following Galobart et al. (2004). The colorimetric fan has a numerical scale (score) that ranges from 1 to 15 in the chroma between opaque yellow (1) and intense orange (15).

On the day before the beginning of the experiment, 80 eggs were collected at random 20 referring to each experimental group - and analyzed for yolk color, to be used as reference (zero time). The yolk color was evaluated on the 7th, 14th, 21st, and 28th days after the experimental diets were supplied, by three evaluators, using four yolks per replicate in a petri dish on a white surface, according to the methodology proposed by Santos-Bocanegra et al. (2004).

Analyses were performed using the SAEG statistical analysis system version 9.1 (Sistema..., 2007). For the statistical analyses, the effects of experimental diets on the performance variables were determined by an initial analysis of variance at 0.05 probability level; when means were statistically significant, they were compared by Tukey's test at 0.05 probability level. The statistical model utilized was:

$$
\hat{Y} i j=\mu+R i+\varepsilon i j
$$

where: $\hat{Y} \mathrm{ij}=$ individual observation in experimental diet $\mathrm{i}$ and replicate $\mathrm{j} ; \mu=$ effect of the overall mean; $\mathrm{Ri}=$ effect of experimental diet ( $\mathrm{i}=1,2,3,4$, and 5); and $\varepsilon \mathrm{ij}=$ random error associated with each observation ij.

Linear Response Plateau (LRP) equations were estimated for color as a function of periods to estimate the plateau or point of saturation of the yolk color, respecting the significant breakdowns of the degrees of freedom and sum of squares. Mean values for the qualitative variables with significant effect were compared by Tukey's test at 0.05 probability level. The statistical model utilized for the analysis of yolk color data was: $\mathrm{Yijk}=\mu+\mathrm{Ri}+\varepsilon i \mathrm{k}+\mathrm{Pj}+\mathrm{RPij}+\varepsilon \mathrm{ijk}$, where: Yijk $=$ observation of individual in treatment $\mathrm{i}$, at age $\mathrm{j}$, in replicate $\mathrm{k} ; \mu=$ effect of the overall mean; $\mathrm{Ti}=$ effect of experimental diets $(i=1,2,3,4$, and 5); $i \mathrm{ik}=$ random error of the plot associated with each observation $\mathrm{ik} ; \mathrm{Pj}=$ effect of periods $(j=7,14,21$, and 28 days); TPij $=$ effect of the interaction between experimental diets and periods; and cijk = random error of the subplot associated with each observation ijk.

\section{RESULTS AND DISCUSSION}

There were no statistically significant differences for any of the performance and egg quality variables $(\mathrm{P}>0.05)$, as shown in Tables 2 and 3 . The sorghum, participating as the main energy source in the diet, did not demonstrate any other contraindication for its use but for the reduced egg yolk color. The synthetic pigments did not interfere with the bird performance variables, since their nutritional requirements were met.

Our results agree with those reported by Moura et al. (2010a), who evaluated the replacement of corn by sorghum at equidistant levels for Japanese laying quail and concluded that replacing $100 \%$ of low-tannin sorghum with corn is a viable practice.

Analyses of yolk color showed differences and a significant interaction between experimental diets and periods $(\mathrm{P}<0.05)$, as shown in Table 4 . Mean comparison by Tukey's test revealed that until the seven experimental days, all yolks showed a score equivalent to that obtained with the corn-based diets. The reference value for the colorimetric score obtained on experimental day "zero" was 5.65 .

Table 2. Mean values for Japanese quail performance variables

\begin{tabular}{lccccc}
\hline \multicolumn{1}{c}{ Experimental diet } & $\begin{array}{c}\text { Egg } \\
\text { production } \\
(\% / \text { quail/day })\end{array}$ & $\begin{array}{c}\text { Feed intake } \\
(\mathrm{g} / \text { quail/day })\end{array}$ & $\begin{array}{c}\text { Egg weight } \\
(\mathrm{g})\end{array}$ & $\begin{array}{c}\text { Egg mass } \\
(\mathrm{g} / \mathrm{g})\end{array}$ & $\begin{array}{c}\text { Feed } \\
\text { conversion } \\
(\mathrm{g} / \mathrm{g})\end{array}$ \\
\hline Diet with corn & $95.75 \pm 2.60$ & $32.70 \pm 1.25$ & $11.26 \pm 0.24$ & $8.52 \pm 0.14$ & $3.84 \pm 0.15$ \\
Diet with sorghum (DS) & $92.57 \pm 3.56$ & $31.07 \pm 0.72$ & $10.88 \pm 0.23$ & $8.75 \pm 0.32$ & $3.70 \pm 0.24$ \\
DS + yellow & $96.64 \pm 1.78$ & $31.39 \pm 1.14$ & $11.68 \pm 0.44$ & $8.29 \pm 0.47$ & $3.80 \pm 0.28$ \\
DS + yellow + red & $94.25 \pm 1.15$ & $30.55 \pm 2.20$ & $11.20 \pm 0.48$ & $8.26 \pm 0.31$ & $3.70 \pm 0.22$ \\
DS + red & $92.77 \pm 4.23$ & $30.97 \pm 1.41$ & $11.15 \pm 0.38$ & $8.33 \pm 0.42$ & $3.72 \pm 0.22$ \\
\hline CV $(\%)$ & 3.34 & 4.09 & 3.45 & 3.17 & 6.06 \\
\hline
\end{tabular}

${ }^{1-}$ Coefficient of variation 
Table 3. Mean values for Japanese quail egg quality variables

\begin{tabular}{|c|c|c|c|c|c|c|c|}
\hline \multirow{2}{*}{ Experimental diet } & \multicolumn{3}{|c|}{ Weight $(\mathrm{g})$} & \multicolumn{3}{|c|}{ Percentage } & \multirow{2}{*}{$\begin{array}{c}\text { Shell } \\
\text { thickness } \\
(\mathrm{mm})\end{array}$} \\
\hline & Yolk & Albumen & Shell & Yolk & Albumen & Shell & \\
\hline \multirow{2}{*}{ R1: Diet with corn } & 3.85 & 7.39 & 0.98 & 31.32 & 60.47 & 8.03 & 0.275 \\
\hline & \pm 0.21 & \pm 0.21 & \pm 0.07 & \pm 1.23 & \pm 0.98 & \pm 0.40 & \pm 0.013 \\
\hline \multirow{2}{*}{$\begin{array}{l}\text { R2: Control diet with } \\
\text { sorghum (DS) }\end{array}$} & 3.78 & 7.26 & 1.04 & 30.68 & 60.88 & 8.41 & 0.282 \\
\hline & \pm 0.063 & \pm 0.17 & \pm 0.04 & \pm 0.45 & \pm 0.60 & \pm 0.32 & \pm 0.016 \\
\hline \multirow{2}{*}{ R3: DS + yellow } & 3.89 & 7.65 & 1.06 & 30.92 & 60.70 & 8.38 & 0.294 \\
\hline & \pm 0.29 & \pm 0.36 & \pm 0.03 & \pm 1.88 & \pm 1.94 & \pm 0.15 & \pm 0.010 \\
\hline \multirow{2}{*}{$\begin{array}{l}\text { R4: DS + yellow + } \\
\text { red }\end{array}$} & 3.78 & 7.45 & 1.01 & 30.86 & 60.87 & 8.28 & 0.287 \\
\hline & \pm 0.086 & \pm 0.35 & \pm 0.06 & \pm 0.83 & \pm 1.03 & \pm 0.49 & \pm 0.010 \\
\hline \multirow{2}{*}{ R5: DS + red } & 3.80 & 7.32 & 1.05 & 31.18 & 60.05 & 8.52 & 0.293 \\
\hline & \pm 0.052 & \pm 0.28 & \pm 0.03 & \pm 0.91 & \pm 0.90 & \pm 0.15 & \pm 0.012 \\
\hline $\mathrm{CV}(\%)^{1}$ & 4.32 & 4.54 & 5.19 & 3.83 & 1.97 & 4.15 & 3.86 \\
\hline
\end{tabular}

${ }^{1-}$ Coefficient of variation

Table 4. Mean values for the colorimetric score of yolk of eggs from Japanese quail from 7 to 28 days of age

\begin{tabular}{|c|c|c|c|c|}
\hline \multirow{2}{*}{ Experimental diet } & \multicolumn{4}{|c|}{ Period (days) } \\
\hline & 7 & 14 & 21 & 28 \\
\hline R1: Diet with corn & $5.80 \pm 0.48 \mathrm{ab}$ & $5.50 \pm 0.31 b$ & $5.50 \pm 0.35 b$ & $5.35 \pm 0.29 b$ \\
\hline R2: Diet with sorghum (DS) & $4.15 \pm 0.45 \mathrm{a}$ & $1.25 \pm 0.25 \mathrm{a}$ & $1.85 \pm 0.42 \mathrm{a}$ & $1.90 \pm 0.38 \mathrm{a}$ \\
\hline R3: DS + yellow & $6.25 \pm 1.16 b$ & $5.70 \pm 0.54 b$ & $5.80 \pm 0.36 b$ & $5.55 \pm 0.37 b$ \\
\hline $\mathrm{R} 4: \mathrm{DS}+$ yellow + red & $6.90 \pm 0.22 b c$ & $11.95 \pm 0.45 \mathrm{c}$ & $11.70 \pm 0.37 \mathrm{c}$ & $12.00 \pm 0.47 \mathrm{c}$ \\
\hline R5: DS + red & $7.60 \pm 0.52 b c$ & $12.05 \pm 0.51 \mathrm{c}$ & $11.75 \pm 0.18 \mathrm{c}$ & $12.20 \pm 0.33 c$ \\
\hline Source of variation & \multicolumn{2}{|c|}{ P-value } & \multicolumn{2}{|c|}{ Coefficient of variation } \\
\hline Diet & \multicolumn{2}{|c|}{$137.2183^{* *}$} & \multicolumn{2}{|c|}{$9.87 \%$} \\
\hline Period & \multicolumn{2}{|c|}{$6.5403^{* *}$} & \multicolumn{2}{|c|}{$6.23 \%$} \\
\hline Diet $\times$ period & \multicolumn{2}{|c|}{$10.6674^{* *}$} & \multicolumn{2}{|c|}{--} \\
\hline
\end{tabular}

**Significant effect at 0.01 probability level by the $\mathrm{F}$ test; Means followed by different letters in the column differ at 0.05 probability level by Tukey's test.

After the effects of the "period $\times$ experimental diets" were broken down and periods were analyzed, fixing the treatments, regression equations were adjusted by the Linear Response Plateau (LRP) model, which best described the response of yolk color as a function of time, as shown in Table 5 and Figure 1.

Quail receiving the sorghum-based diet had their yolk color score reduced throughout the periods from the 7th day onwards, reaching the lowest levels around the 16th day. This decreased yolk pigmentation is explained by the depletion of the hepatic and follicular pigment reserves, required by the birds' high egg-laying rate at the time, coupled with the deficiency of pigments derived from the experimental diet.

Table 5. Linear Response Plateau equations and time for stabilization of the yolk color score according to experimental diets

\begin{tabular}{lcccc}
\multicolumn{1}{c}{ Treatment } & Equation & $\mathrm{R}^{2}$ & Plateau (days) & Score \\
\hline R1: Diet with corn & - & - & - & - \\
R2: Diet with sorghum (DS) & $\hat{\mathrm{Y}}=7.51-0.562 \mathrm{P}$ & 0.96 & 16.70 & 2.25 \\
R3: DS + yellow (DSY) & - & - & - & - \\
R4: DS + yellow + red (DSYR) & $\hat{\mathrm{Y}}=1.98+1.06 \mathrm{P}$ & 0.98 & 15.08 & 12.64 \\
R5: DS + red (DSR) & $\hat{\mathrm{Y}}=2.53+0.90 \mathrm{P}$ & 0.96 & 15.62 & 12.81 \\
\hline
\end{tabular}




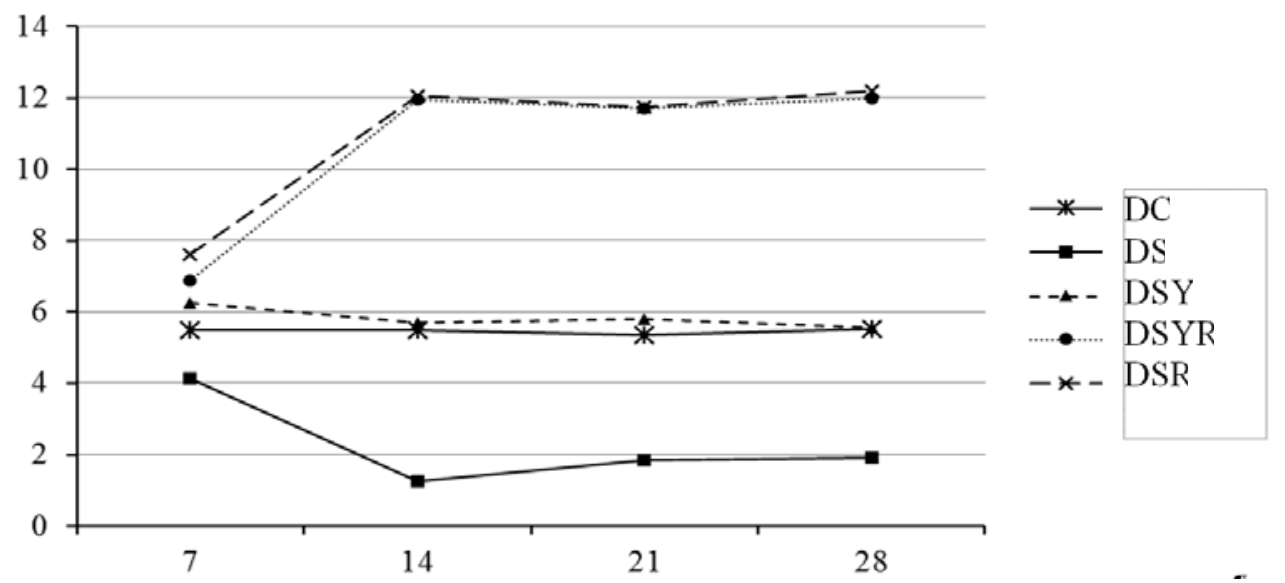

Figure 1. Colorimetric scores of egg yolks according to experimental diets and experimental periods.

On the other hand, birds that consumed diets complemented with the synthetic yellow pigment kept their colorimetric score between five and six, corresponding to that observed in yolks from birds fed corn-based diets. High scores, greater than 12, were observed in yolks from birds supplemented with canthaxanthin. Saturation, or the maximum value obtained with the red pigment, was observed around the second week after the experimental diets started to be supplied. This response indicates a cumulative effect of dietary pigments on the maturing follicles, originating from the hepatic systems, which were consequently transferred to the yolks.

Combined supplementation of the yellow and red pigments provided yolks with color scores equivalent to those obtained with canthaxanthin separately, following the same linear-plateau pattern observed when the red pigment was supplemented separately. This response points to the use of separate supplementation of the red pigment when higher colorimetric scores are aimed, especially when the diet has lowcarotenoid ingredients in its formulation.

Compared with the effect observed in layer hens, the yolk pigmentation results were superior to those reported by Gurbuz et al. (2003), who obtained a colorimetric score of 10.30 after supplementing a white corn-based diet with apoester and canthaxanthin. However, the results differ from the responses obtained by Halaj et al. (1999), who observed a linear increase in yolk pigmentation after seven days of supplementation. Likewise, Baiao et al. (1999) and Santos-Bocanegra et al. (2004) also found colorimetric scores ranging from 12 to 13 when combining the yellow (apo-ester) and red (canthaxanthin) synthetic pigments.

The commercial standard for eggs from freerange chicken is a colorimetric score between 10 and 12. Thus, an alternative to obtain higher colorimetric scores is the separate use of canthaxanthin, as remarked by Garcia et al. (2002). These authors obtained a color score of around 14 with supplementation of $60 \mathrm{ppm}$ canthaxanthin $10 \%$ to Hisex Brown layer hens fed a corn-based diet.

Though more expensive, synthetic pigments have a greater pigmentation efficiency when compared with natural additives such as derivatives of calendula or marigold, paprika, and annatto (Baiao et al., 1999; Garcia et al., 2002). Results obtained by Moura et al. (2011) described maximum saturation between 8 and 9 colorimetric scores after supplementing laying quail with natural extracts of marigold and paprika.

This contrast is due mainly to the greater concentration and solubility of xantophils in the synthetic sources that are absorbed in the ileum together with the fatty acids in the form of micelles, esterified and stored mainly in the adipose tissue, skin, and liver as hydroxycarotenoids (Galobart et al., 2004). Supplementation with natural and synthetic sources may lead to adequate scores, provided that it is used under a yellow:red pigment ratio of 2:1, as reported by Baio et al. (1999). 
Quail eggs are usually consumed whole and cooked, which denotes little exposure of the yolk and little impact on the consumer's choice (Moura et al., 2009). However, market demands require management strategies to meet the final consumer and provide a product with the desired profile, including the yolk color. Therefore, supplementation of synthetic pigments to these birds should be evaluated particularly under the perspective of the benefit-cost ratio.

\section{CONCLUSIONS}

Total substitution of corn by sorghum interfered negatively with the yolk pigmentation. Supplementation of diets with synthetic pigments did not influence quail performance or egg quality, except for the yolk chromatic profile. Supplementation of synthetic pigments to quail improved the yolk colorimetric score, but also increased the feed cost. Its use must be evaluated by the calculation of economic viability within the production scale.

\section{REFERENCES}

BAIAO, N.C.; MENDEZ, J.; MATEOS, J.; GARCIA, M.; MATEOS, G.G. Pigmenting efficacy of several oxycarotenoids on egg yolk. J. Appl. Poult. Res., v.8, p.472-479, 1999.

BARRETO, S.L.T; PEREIRA, C.A; UMIGI, R.T. et al. Determinação da exigência nutricional de cálcio de codornas japonesas na fase inicial do ciclo de produção. Rev. Bras. Zootec., v.36, p.6878, 2007.

DSM - Nutrional Products of North América. Carophyll $^{\circledR}$ for perfect yolks. In: CAROTENOIDS in animal nutrition and health. Disponível em: $<$ http://www.dsm.com/markets/anh/en_US/speci es/species-poultry/species-poultrypigmentation.html $>$. Acesso em: 10/05/2014.

GALOBART, J.; SALA, R.; RINCO, X. et al. Egg yolk color as affected by saponification of different natural pigmenting sources. J. Appl. Poult. Res., v.13, p.328-334, 2004.

GARCIA, E.A; MENDES, A.A; PIZZOLANTE, C.C. et al. Efeito dos níveis de cantaxantina na dieta sobre o desempenho e qualidade dos ovos de poedeiras comerciais. Rev. Bras. Cienc. Avi., v.4, p.01-07, 2002.
GURBUZ, Y; YASAR, S.; KARAMAN, M. Effect of red pepper on egg yolk colour and egg production. Int. J. Poult. Sci., v.2, p.107-111, 2003.

HALAJ, M.; HALAJ, P.; VALASEK, F. et al. The effect of synthetic pigment addition to feed on the color of hen egg yolk. Cz. J. Anim. Sci., v.44, p.187-192, 1999.

MOURA, A.M.A.; FONSECA, J.B.; MELO, E.A. et al. Características sensoriais de ovos de codornas japonesas (Coturnix japonica, Temminck e Schlegel, 1849) suplementadas com pigmentantes sintéticos e selenometionina. Cienc. Agrotecnol., v.33, p.1594-1600, 2009.

MOURA, A.M.A.; FONSECA, J.B.; RABELLO, C.B.V. ; TAKATA, F.N.; OLIVEIRA, N.T.E. Desempenho e qualidade do ovo de codornas japonesas alimentadas com rações contendo sorgo. Rev. Bras. Zootec., v.39, p.2697-2702, 2010a.

MOURA, A.M.A.; FONSECA, J.B.; TAKATA, F.N. et al. Energia metabolizável aparente de alimentos determinados em codornas japonesas (Coturnix japonica). Arq. Bras. Med. Vet. Zootec., v.62, p.178-183, 2010b.

MOURA, A.M.A.; TAKATA, F.N.; NASCIMENTO, G.R. et al. Pigmentantes naturais em rações à base de sorgo para codornas japonesas em postura. Rev. Bras. Zootec., v.40, p.2443-2449, 2011.

NORDSTROM, J.O; OUSTERHOUT, L.E. Estimation of shell weight and shell thickness from egg specific gravity and egg weight. Poult. Sci., v.61, p.1991-1995.1982.

NUTRIENT requirements of poultry. 9.ed. Washington: NRC, 1994. p.44-45.

OLIVEIRA, A.M.; FURLAN, A.C.; MURAKAMI, A.E. et al. Exigência nutricional de lisina para codornas japonesas (Coturnix coturnix japonica) em postura. Rev. Bras. Zootec., v.28, p.10501053, 1999.

SANTOS-BOCANEGRA, E.; OSPINA-OSORIO, X.; OVIEDO-RONDÓN, E.O. Evaluation of Xanthophylls Extracted from Tagetes erectus (Marigold Flower) and Capsicum Sp. (Red Pepper Paprika) as a Pigment for Egg-yolks Compare with Synthetic Pigments. Int. J. Poult. Sci., v.3, p.685-689, 2004. 
SEIBEL, N.F.; SCHOFFEN, D.B.; QUEIROZ, M.I.; SOUZA-SOARES, L.A. Caracterização sensorial de ovos de codornas alimentadas com dietas modificadas. Cienc. Tecnol. Ali., v.30, p.884-889, 2010.

SILVA, D.J.; QUEIROZ, A.C. Análise de alimentos: métodos químicos e biológicos. 3.ed. Viçosa: UFV, 2002. 235p.
SISTEMA de análises estatísticas e genéticas (SAEG). Versão 8.1. Viçosa: UFV, 2007. 301p.

TEMMINCK, C.; H. SCHLEGEL. Description des oiseaux observés au Japon par les voyageurs Hollandais. In: VON SIEBOLD, P.F. (Ed). Aves. [s.1.]: [s.n.], 1848. 142p. 